Dostępne online www.journals.wco.pl/los

Zeszyty Naukowe WCO, Letters in Oncology Science 2020;17(2):85-91

CrossMark
Praca poglądowa/Review paper

\section{Letters in Dncology Science}

ISSN 2543-6724

ZESZYTY NAUKOWE WIELKOPOLSKIEGO CENTRUM ONKOLOGII

\title{
Zastosowanie radioimmunoterapii w leczeniu chłoniaków
}

\author{
The radioimmunotherapy in lymphoma
}

\author{
Mikołaj Kuta, Agata Pietrzak ${ }^{1,2}$ \\ ${ }^{1}$ Zakład Medycyny Nuklearnej, Wielkopolskie Centrum Onkologii w Poznaniu. \\ ${ }^{2}$ Katedra i Zakład Elektroradiologii, Uniwersytet Medyczny im. K. Marcinkowskiego w Poznaniu
}

\section{Streszczenie}

Radioimmunoterapia ( $\mathrm{z}$ ang. radioimmunotherapy; RIT) jest metodą leczenia ukierunkowanego biologicznie, wykorzystywaną u chorych z rozpoznanym chłoniakiem nieziarnicznym z komórek B (z ang. non-Hodgkin lymphoma, NHL). RIT może być stosowany jest jako metoda pierwszego rzutu, a także element leczenia skojarzonego z chemioterapią. Pomimo uznanej skuteczności w leczeniu NHL, RIT jest rzadko stosowana.

\begin{abstract}
Radioimmunotherapy (RIT) is a targeted therapy combining radiobiological and immunological characteristics. RIT has been considered effective in terms of B-cell non-Hodgkin's lymphomas (NHL) treatment and it can be used as the main therapy or as the element of the combined RIT and chemotherapy. Despite RIT's effectiveness in NHL therapy, it is still rarely used.
\end{abstract}

Słowa kluczowe: chłoniaki nieziarnicze, onkologia, radioimmunoterapia

Keyword: non-Hodgkin lymphomas, oncology, radioimmunotherapy

Adres do korespondencji

Mikołaj Kuta

Wielkopolskie Centrum Onkologii, ul. Garbary 15, 61-866 Poznań, Polska

e-mail:m.kuta93@gmail.com 


\section{Wstęp}

Chłoniaki złośliwe są najczęstszym typem nowotworów hematologicznych, obejmującym układ chłonny. Histologicznie, wywodzą się z limfocytów szpikozależnych (z łac. bursa Fabricii, torebka Fabrycjusza, B), grasiczozależnych ( $\mathrm{z}$ łac. thymus, T), a także komórek układu odpornościowego (immunologicznego, $\mathrm{z}$ ang. natural killer T-cells, NKT). Transformacja nowotworowa może być zapoczątkowana w tkance limfatycznej śledziony, grasicy, szpiku kostnego, węzłach chłonnych lub też poza ww. strukturami. Histologicznie, chłoniaki dzieli się na nie-Hodgkina (z ang. non-Hodgkin's lymphoma; NHL, tzw. nieziarnicze) i Hodgkina (z ang. Hodgkin's lymphoma; HL, tzw. ziarnicze). Najczęstszym typem NHL jest B, stanowiący około 95\% wszystkich przypadków chłoniaka złośliwego nieziarniczego. W Polsce, NHL stanowi w przybliżeniu $2 \%$ wszystkich nowych przypadków zapadalności na nowotwory złośliwe (w 2018r. odnotowano blisko 4000 zachorowań i 2150 zgonów). Szczyt przypada na okres między 15. a 40 rokiem życia (r.ż.), a następnie: 60. 8o. r.ż. [1].

Wśród czynników predysponujących do zachorowań na NHL, wyróżniamy infekcje upośledzające lub wynikającezniewydolności układu immunologicznego, np. zakażenieludzkim wirusem niedoboru odporności (z ang. human immunodeficiency virus, HIV) czy Epstein-Barr, a także choroby autoimmunologiczne (Hashimoto, celiakia i choroba Leśniowskiego-Crohna) [2-4].

Ponieważ rozwojowi NHL nie towarzyszą charakterystyczne objawy, chorobę rozpoznaje się często w wysokim stopniu zaawansowania. Najczęstszym przejawem NHLjest miejscowa lub rozlana limfadenopatia węzłów szyjnych, pachowych i pachwinowych, które mogą być mylone z toczącym się stanem zapalnym. U części chorych, niezależnie od limfadenopatii, występują: utrata apetytu i masy ciała, gorączka, czy też nocne poty (nazywane objawami typu B). W przebiegu NHL, może dochodzić także do niedokrwistości hemolitycznej oraz upośledzonej odpowiedzi immunologicznej na rozwijające się infekcje. Manifestacją wysokiego stopnia zaawansowania NHL jest tworzenie się mas nowotworowych, które uszkadzają naciekane narządy [5,6]. Diagnostyka różnicowa HL i NHL, poza rozpoznaniem histopatologicznym, opiera się także na określeniu liczby i lokalizacji zajętych procesem nowotworowym grup węzłów chłonnych. W przebiegu HL, zmiany obejmują węzły chłonne pachowe, nadobojczykowe i szyjne, a także sąsiadujące z nimi struktury w sposób uporządkowany, gdy w przebiegu NHL obserwowany jest naciek losowy. Ponadto, HL zasadniczo nie występuje w postaci pozawęzłowej w przeciwieństwie do NHL.

Klinicznie, NHL dzielimy na te o niskim stopniu złośliwości czy też powolnym przebiegu (tzw. indolentne) i wysokim lub bardzo wysokim stopniu złośliwości (tzw. chłoniaki o agresywnym przebiegu). Podział wynika z tempa proliferacji komórek neoplastycznych oraz momentu wystąpienia objawów. Chłoniaki indolentne cechują się powolną proliferacją, możliwym bezobjawowym przebiegiem oraz niską chemiowrażliwością. W przypadku chłoniaków agresywnych, obserwowany jest gwałtowny proces proliferacji, połączony z narastającymi dolegliwościami, co zwiększa skuteczność leczenia cytostatykami i pozwala na szybsze wykrycie choroby.

Światowa Organizacja Zdrowia (z ang. World Health Organization, WHO), rekomenduje następujący podział chłoniaków (główne typy):

1. Nowotwory limfoidalne z komórek prekursorowych

2. Nowotwory z dojrzałych komórek B

3. Nowotwory z dojrzałych komórek $\mathrm{T} / \mathrm{NK}$

4. Chłoniaki Hodgkina

Dodatkowo, WHO wyróżnia zaburzenia limfoproliferacyjne, związane z niedoborem odporności, które mogą przekształcić się w chłoniaki [7].

Badanie histopatologiczne chłoniaków obejmuje ocenę węzła chłonnego, torebki łącznotkankowej lub fragmentu tkanki, przy czym biopsję gruboigłową wykonuje się przy braku innej możliwości pobrania wycinka 
tkanki. Ocena poszerzona jest zwykle o badanie immunohistochemiczne lub cytometrię przepływową. Diagnostyka różnicowa zmian zapalnych i chłoniaków, opiera się przede wszystkim na określeniu, czy linie komórkowe są monoklonalne (chłoniaki) czy poliklonalne (stany zapalne) z użyciem łańcuchowej reakcji polimerazy (z ang. polymerase chain reaction, PCR). Dodatkowo, coraz częściej stosuje się także techniki badające aberracje (nieprawidłowości) genetyczne. Diagnostyka obrazowa chłoniaka złośliwego obejmuje ultrasonografię węzłów chłonnych (z ang. ultrasonography, USG), tomografię komputerową ze wzmocnieniem kontrastowym (z ang. contrast-enhanced computed tomography, ce CT), a także pozytonową tomografię emisyjną/tomografię komputerową ( $\mathrm{z}$ ang. positron emission tomography/computed tomography, PET/ CT) z użyciem radiofarmaceutyków ${ }^{18} \mathrm{~F}$-fluordeoksyglukozy $\left({ }^{18} \mathrm{~F}-\mathrm{FDG}\right.$, najczęściej) czy ${ }^{18} \mathrm{~F}$-fluorotymidyny $\left({ }^{18} \mathrm{~F}-\mathrm{FLT}\right)$. W przypadku chłoniaków związanych z układem nerwowym, badaniem z wyboru jest magnetyczny rezonans jądrowy (z ang. magnetic resonance imaging, MRI). Leczenie HL i NHL opiera się na zastosowaniu cytostatyków (leczenie systemowe), a także immuno- i radioimmunoterapii (z ang. radioimmunotherapy, RIT) $[2,4,5]$. Z uwagi na znaczną radiooporność wszystkich typów chłoniaków, w praktyce stosowana jest jedynie miejscowa radioterapia (w przypadku pojedynczych węzłów chłonnych).

\section{Cel pracy}

Celem niniejszej pracy jest omówienie radioimmunoterapii jako metody leczenia NHL w oparciu o dostępne piśmiennictwo naukowe.

\section{Material i metoda}

Treść niniejszej pracy poglądowej powstała w oparciu o bazę bibliograficzną z lat 2013-2019, odnoszącą się do terapii chłoniaków złośliwych. Opracowane dane pochodzą z zasobów National Center for Biotechnology Information (NCBI; Stany Zjednoczone Ameryki, 8600 Rockville Pike, Bethesda MD, 20894 USA). Autorzy niniejszego artykułu użyli narzędzi zaawansowanego wyszukiwania z wykorzystaniem następujących słów kluczowych: chłoniak złośliwy (z ang. lymphoma malignant) immunoterapia (z ang. immunotherapy), RIT, radioimmunoterapia (z ang. radioimmunotherapy), NHL. Użyte w treści pracy polskojęzyczne opracowania, pochodzą spoza ww. bazy naukowej.

\section{Omówienie}

Ocena stopnia zaawansowania klinicznego chłoniaków złośliwych, obejmujących układ limfatyczny, opiera się na klasyfikacji z Lugano (2014r.). Stopniowania chłoniaków pierwotnie pozawęzłowych, dokonuje się na podstawie schematów dedykowanych poszczególnym typom tego schorzenia. Klasyfikacja z Lugano dzieli chłoniaki na cztery grupy, spośród których I i II oznacza niski, a III i IV - wysoki stopień zaawansowania choroby. Zasadniczo, stopień I opisany jest jako: zajęcie pojedynczego węzła lub grupy węzłów przyległych, a także pojedynczą zmianę. Stopień II oznacza naciek dwóch lub kilku grup węzłów chłonnych, znajdujących się po tej samej stronie przepony. III typ określony jest jako zajęcie węzłów chłonnych powyżej przepony lub naciek samego narządu, a IV - naciek dowolnej struktury spoza układu limfatycznego. Podział ten uwzględnia zarówno cechy histologiczne i czynniki rokownicze, jak również anatomiczną lokalizację zmian, np. obecność guzków pozawęzłowych, a także mas (m.in. II stopień zaawansowania z pojedynczą zmianą masywną, większą niż 10 centymetrów (cm) lub zajmującą 1/3 szerokości klatki piersiowej, ocenianej w ${ }_{\text {ce }} \mathrm{CT}$ na każdej wysokości odcinka kręgosłupa piersiowego) [4,5].

\section{- Podstawy radioimmunoterapii}

RIT jest metodą leczenia celowanego, łączącego cechy procesów immunologicznych i własności radiobiologiczne tkanki nowotworowej. Preparaty radiofarmaceutyczne, stosowane w RIT, składają się $\mathrm{z}$ radionuklidu, połączonego $\mathrm{z}$ odpowiednim przeciwciałem monoklonalnym (z ang. monoclonal antibodies, mAb). Celem takiego połączenie jest konieczność powiązania mAb z właściwym antygenem na powierzchni komórek nowotworowych [8-10]. Ekspozycja materiału genetycznego komórek NHL 
(kwas deoksyrybonukleinowy, DNA) na promieniowanie jonizujące, pochodzące z rozpadu jąder izotopu promieniotwórczego, skutkuje powstawaniem wolnych rodników i rozerwaniem nici DNA komórki, a następnie apoptozą (będącą wynikiem uwrażliwienia komórki na działanie cytostatyku) lub nekrozą (śmierć, zniszczenie) komórki patologicznej. Ograniczeniem RIT jest fakt, że efektywny zasięg jonizacji jest większy niż rozmiar komórki, toteż uszkodzeniu mogą ulegać również tkanki prawidłowe. Wysoką skuteczność metody RIT wykazano w grupie chorych z rozpoznanym NHL opornym na leczenie, nawrotowym, a także w przypadku NHL o niskim stopniu zaawansowania [8-10].

\section{- Najczęściej stosowane preparaty}

Pierwszym preparatem mAb-anty-CD2O, zatwierdzonym w 1997r. przez Amerykańską Agencję ds. Żywności i Leków (z ang. Food and Drug Administration, FDA) był tzw. Rytuksymab. Obecnie, dopuszczone do stosowania są dwa leki opierające się na mysich przeciwciałach, tzw. anty-CD20: znakowany izotopem itru-90 90Y-ibritumomab, Tiuxetan (w preparacie Zevalin, Spectrum Pharmaceuticals) i znakowany izotopem jodu-131, ${ }^{131}$ I-tositumomab (w leku Bexxar, GlaxoSmithKline) [8-10]. CD20 jest antygenem prezentowanym przez limfocyty B oraz większość chłoniaków z komórek B. Z uwagi na to, że CD2O nie występuje w zróżnicowanych komórkach plazmatycznych i prekursorowych limfocytów B, stosowanie tej metody uznawane jest za bezpieczne, jednakże odnotowano przypadki wystąpienia skutków ubocznych, w tym: ciężkich powikłań hematologicznych $[8,10]$. Wykorzystanie mysich przeciwciał wynika z niższego - w stosunku do przeciwciał ludzkich - biologicznego okresu półtrwania (72 godziny vs kilka tygodni), co istotnie obniża toksyczność terapii [11].

\section{- Charakterystyka leków stosowanych w RIT i przykłady dawkowania}

Zevalin jest preparatem stosowanym w terapii opornego na leczenie chłoniaka grudkowego (z ang. follicular lymphoma, FL) w schemacie samodzielnym lub skojarzonym z chemioterapią. W budowie cząsteczek preparatu wyróżniamy obecność izotopu ${ }^{90} \mathrm{Y}$, będącego emiterem cząstek beta $(\beta)$ o energii charakterystycznej 2,293 megaelektronovoltów ( $\mathrm{MeV})$, czasie półtrwania $\left(\mathrm{T}_{1 / 2}\right) 64$ godziny (g.) i zasięgu 5 milimetrów (mm). Alternatywę stanowi znakowanie preparatu Zevalin izotopem indu-111 $\left.{ }^{111} \mathrm{In}\right)$, który cechuje większy zasięg promieniowania i wyższa efektywność terapeutyczna (tzw. efekt crossfire, pozwalający zniszczyć większą liczbę komórek NHL). Stosowanie leku nie wymaga hospitalizacji chorego poddanego terapii, który nie emituje promieniowania jonizującego o znacznym zasięgu [12-14].

Bexxar jest lekiem $m A b$-anty-CD2O, znakowanym izotopem jodu ${ }^{131} \mathrm{I}$, będącym emiterem promieniowania $\beta$ o energii $0,606 \mathrm{MeV}$ i promieniowania $\gamma$ o energii $0,364 \mathrm{MeV}$. $\mathrm{T}_{1 / 2}{ }^{131} \mathrm{I}$ wynosi $193 \mathrm{~g}$., a efektywny zasięg strumienia cząstek w tkance to $0,8 \mathrm{~mm}$. Ze względu na właściwości fizyczne izotopu, chorzy leczeni Bexxar muszą zostać poddani badaniom dozymetrycznym po zakończonej terapii (stanowią otwarte źródło promieniowania jonizującego o wysokiej energii). Dozymetrię można wykonać podając 450 miligramów (mg) Tositumabu w czasie 60 minut (min), a następnie $185 \mathrm{MBq}$ w ciągu 20min. Pomiary dozymetryczne i badanie biodystrybucji (rozmieszczenia czasowo-przestrzennego radiofarmaceutyku w tkance), przeprowadza się w schemacie: trzy razy dziennie przez siedem kolejnych dni, co narzuca konieczność hospitalizacji. Obecnie, preparat ten stosowany jest rzadko (przypadki opornego na leczenie NHL) [12,13].

Wymaganym postępowaniem w leczeniu RIT jest zastosowanie nieznakowanego izotopem promieniotwórczym przeciwciała (np.: Rytuksymab, Mabathera). Działanie to ma służyć wysyceniu komórek prezentujących na swojej powierzchni antygen CD20, niebędących jednocześnie komórkami nowotworowymi, co zapobiega gromadzeniu się znacznika poza nowotworem i zwiększa stopień gromadzenia w guzie kolejnych dawek terapeutycznych. W przypadku chorych leczonych preparatem Zevalin, Rituximab podawany jest w schemacie kilkugodzinnych wlewów w okresie 6.-8. dni poprzedzających terapię zasadniczą. Dawka terapeutyczna Zevalinu wynosi 11-14 MBq/kg masy ciała chorego przy 100 ooo-149 ooo płytek krwi na ml objętości puli krwi [10,14]. Dawkowanie Bexxar opiera się na pomiarze dawki pochłoniętej (D) przez ciało osoby leczonej, która istotnie koreluje z przewidywaną toksycznością leczenia. Przy liczbie płytek krwi $<150$ 000/ml, D nie powinna przekroczyć 65-75 centygreyów (cGy) [12,13]. 


\section{- Skuteczność RIT w leczeniu NHL}

RIT znajduje szczególne zastosowanie w leczeniu chłoniaka złośliwego typu FL oraz postaci rozlanej z dużych komórek B (z ang. Diffuse large B-cell lymphoma; DLBCL), jako metoda podstawowa lub uzupełnienie leczenia systemowego. Przedmiotem zainteresowania badaczy jest ponadto rola RIT w terapii chorych kwalifikowanych do autologicznego przeszczepu komórek macierzystych (z ang. autologous stem cell transplantation, ASCT) [15]. Badanie przeprowadzone przez Scholz i wsp. wykazało 87\% skuteczność terapii preparatem Zevalin oraz 25,5 miesiąca okresu wstrzymanej progresji u chorych z rozpoznanym FL [15]. Według autorów [13,16], użycie preparatu ${ }^{131}$ I-Tositumab, pozwala uzyskać skuteczność terapii w 95\% przypadkach, i pięcioletnie przeżycia na poziomie 60\% [13,16]. Powyższe dane mogą sugerować, że zastosowanie RIT jako wyłącznej metody terapeutycznej, może prowadzić do wyleczenia choroby i uzyskania zadowalających długoterminowych efektów terapeutycznych.

\section{- Skutki uboczne RIT i ocena odpowiedzi na leczenie}

Wśród najczęstszych skutków ubocznych stosowania RIT, wyróżniamy: przemijające obniżenie liczby granulocytów obojętnochłonnych - neutrocytów (neutropenię), niedokrwistość, małopłytkowość, jako konsekwencję zespołu mielodysplastycznego (zmniejszona liczba krwinek we krwi obwodowej, wywołana ekspozycją na promieniowanie w trakcie stosowania RIT) $[8,11,14]$. Wśród objawów niehematologicznych, wywołanych oddziaływaniem przeciwciał i występujących u około 1\% leczonych RIT, dominują: astenia (ogólne osłabienie), nudności, gorączka, dreszcze, ból głowy i brzucha [12,14]. Możliwe jest również pojawienie się ostrych białaczek szpikowych [8] i wtórnych nowotworów złośliwych, jednak częstotliwość ich występowanie nie jest znacząco większa niż w innych terapiach. Ze względu na możliwe skutki uboczne jednym z niewielu przeciwwskazań do zastosowania RIT jest ponad 25\% nacieczenie szpiku kostnego [8,11,15].

Metodą z wyboru w ocenie skuteczności leczenia NHL jest, bez względu na zastosowany schemat terapeutyczny, badanie ${ }^{18}$ F-FDG PET/CT. Skanowanie należy przeprowadzić po minimum 6 tygodniach od momentu zakończenia leczenia, celem najbardziej precyzyjnej oceny zmian aktywności metabolizmu radiofarmaceutyku w obszarze zainteresowania [8]. Zasady te dotyczą zarówno RIT, jak i każdego protokołu terapeutycznego, wdrażanego wobec chorych z rozpoznanym i leczonym NHL.

\section{- Perspektywy RIT}

Stosunkowo nowym odkryciem jest stosowanie glikoproteiny CD22 - prezentowanej przez limfocyty B w preparacie ${ }^{\circ} Y$ Y-Epratuzumab $m A b$-anty-CD22. Podawanie leku w schemacie: dwie dawki po 740MBq/m2 powierzchni ciała chorego, przypuszczalnie zapewnia wysoki wskaźnik pełnej odpowiedzi w opornym na leczenie NHL z limfocytów B i DLBCL [10,12]. W przyszłości, metoda ta może być stosowana jako alternatywa dla innych schematów RIT. Znakowanie izotopem lutetu-177 $\left.{ }^{177} \mathrm{Lu}\right)$ przeciwciała $m A b$-anty-CD37 ${ }^{177} \mathrm{Lu}-$ Lilitomab mAb-anty-CD37), poddawane jest testom w grupie chorych z NHL, opornym na wszystkie znane metody leczenia [3]. W badaniu klinicznym pierwszej fazy, odpowiedź na leczenie zaobserwowano u 57\% chorych z nawrotowym nieuleczalnym NHL [3]. Badacze przewidują, że leczenie ${ }^{177}$ Lu-Lilitomabem może być wykorzystane szczególnie w przypadku oporności na Rytuksymab (zmniejszenie liczby CD2O na powierzchni komórek nowotworowych) [10,18].

\section{Dyskusja}

RIT jako terapia celowana pierwszego rzutu jest, zdaniem badaczy [11,15], szczególnie skuteczna w przypadku chorych z rozpoznanym chłoniakiem grudkowym - FL, jak również w przypadkach indolentnych, opornych na leczenie, nawrotowych i wcześniej nieleczonych NHL. W porównaniu z innymi metodami, RIT cechuje niska toksyczność. Oznacza to, że wdrożenie RIT w postępowanie wobec chorego onkologicznie, umożliwia stosowanie uzupełniających metod na kolejnych etapach leczenia. Ograniczeniem RIT jest jednakże niska skuteczność w momencie, gdy stanowi metodę uzupełniającą (czyli leczenie II rzutu). W tej grupie chorych zaobserwowano znaczne pogorszenie ogólnego stanu zdrowia i mniej korzystne rokowania. 
Pomimo pomyślnych wyników badań, przeprowadzonych z użyciem licznych grup chorych z rozpoznanym FL, efekty stosowania RIT w kontekście pozostałych typów NHL uzyskano w oparciu o niewielkie próby. Według autorów [11,15], w wybranych przypadkach NHL (wyłączając FL), niezwykle istotnym może okazać się poprzedzenie RIT leczeniem cytostatykami (tzw. immunochemioterapia), co zwiększa skuteczność RIT. Koncepcja ta jest jednakże perspektywą dalszego rozwoju metody i wymaga dalszych badań. U chorych kwalifikowanych do ASCT, zastosowanie schematu leczenia skojarzonego z RIT, pozwala opóźnić progresję choroby, a tym samym - zwiększyć odsetek przeżyć pięcioletnich. Jest to niezwykle istotne z uwagi na brak skutecznych metod leczenia [17]. W terapii chorych, przygotowywanych do ASCT, wdrożenie preparatu Zevalin w protokół z uwzględnieniem napromienienia zmiany, zwiększa efektywność leczenia i nie powoduje istotnego nasilenia jego toksyczności. W większości przypadków, wznowa nowotworowa po zastosowanym ASCT występuje w miejscu ogniska pierwotnego, co wskazuje na niepełne zniszczenie masy. W takim przypadku, zastosowanie Zevalinu służy precyzyjnemu deponowaniu dawki w ognisku pierwotnym, co zwiększa szansę na remisję.

Działania niepożądane, wywołane stosowaniem RIT są przewidywalne i odwracalne, a jednocześnie mniej nasilone w porównaniu z innymi znanymi metodami leczenia przeciwnowotworowego (chemioterapią, radioterapią, samodzielną terapią izotopową). Profil skutków ubocznych pozwala zastosować RIT u chorych w wieku podeszłym, a także tych, których ogólny stan zdrowia nie pozwala na zastosowanie schematu radykalnego. Ograniczeniem metody jest obecnie niewielka liczba wskazań do leczenia oraz brak jednoznacznych wytycznych, dotyczących precyzyjnego wskazania miejsca metody w protokole leczniczym. Ponadto, wysokie koszty, czasochłonność stosowania RIT oraz szeroka dostępność innych protokołów terapeutycznych powoduje, że pomimo przewidywanej skuteczności radioimmunoterapii w leczeniu NHL, nie jest to metoda szeroko stosowana.

\section{Wnioski}

RIT jest metodą, która może być stosowana zarówno jako wyłączna terapia, jak również element leczenia skojarzonego chłoniaków z komórek B. Jednakże, zarówno metodologia RIT, jak i określenie długoterminowych efektów i skutków ubocznych terapii, wymagają dalszych badań.

\section{Konflikt interesu / Conflict of interest}

Nie występuje / None

\section{Etyka / Ethics}

Treści przedstawione w artykule są zgodne z zasadami Deklaracji Helsińskiej, dyrektywami EU oraz ujednoliconymi wymaganiami dla czasopism biomedycznych.

\section{Piśmiennictwo / References}

[1] Dostęp w Internecie: Globocan 2018, Cancer Fact Sheets. Ferlay J, Ervik M, Lam F, Colombet M, Mery L, Piñeros M, Znaor A, Soerjomataram I, Bray F (2018). Global Cancer Observatory: Cancer Today. Lyon, France: International Agency for Research on Cancer. https://gco.iarc.fr/today. Data ostatniej aktualizacji: 01.1.2020.

[2] Younes A. Handbook of Lymphoma. Springer, 2016. ISBN 978-3-319-08467.

[3] Evans A M, Blum K A, Non-Hodgkin Lymphoma. Patology, Imaging and Current Therapy. Springer, 2015. ISBN 978-3-319-13150-4.

[4] Marcus R, Sweetenham J W, Williams M. Lymphoma. Pathology, Diagnosis and Treatment. Second Edition. Cambridge, Cambridge University Press, 2014. ISBN 978-1-107-01059-8.

[5] Cheson B D, Fisher R I, Barrington S F. Recommendations for Initial Evaluation, Staging, and Response 
Assessment of Hodgkin and Non-Hodgkin Lymphoma: The Lugano Classification. Clin. Oncol. 2014; 32: 3059-3068.

[6] Lech-Marańda E, Warzocha K. Ocena stopnia zaawansowania i odpowiedzi na leczenie u chorych na chłoniaka Hodgkina i chłoniaki nie Hodgkina -rekomednacje Międzynarodowej Grupy Roboczej z Lugano. Hematologia 2015; 6, 3: 223-232.

[7] Swerdlow S H, Campo E, Harris N L. WHO Classification of Tumours of Haematopoietic nad Lymphoid Tissues. Revised 4th Edition. Lyon, IARC, 2016. ISBN 978-92-835-4494-3.

[8] Sachpekidis C, Jackson D B, Soldatos T G. Radioimmunotherapy in Non-Hodgkin's Lymphoma: Retrospective Adverse Event Profiling of Zevalin and Bexxar. Pharmaceuticals 2019, 12(4), 141.

[9] Huang G. Nuclear Medicine in Oncology. Molecular Imaging and Target Therapy. Springer, 2019. ISBN 978-981-13-7458-6.

[10] Giovanella L. Nuclear Medicine Therapy. Side Effects and Complications. Springer, 2019. ISBN 978-3030-17494-1.

[11] Schlechter B L, Kim M S, Joyce R M. An update on radioimmunotherapy for lymphoma. J. Hematol. Oncol 2013, 2(2), 163-178.

[12] Aktolun C, Goldsmith S J. Nuclear Medicine Therapy. Principles and Clinical Applications. Springer, 2013. ISBN 978-1-4614-4021-5.

[13] Schimoni A, Zwas S T. Radioimmunotherapy and Autologous Stem-Cell Transplantation in the Treatment of B-Cell Non-Hodgkin Lymphoma. Seminars in nuclear medicine 2016, 46(2):119-125.

[14] Bombardieri E, Seregni E, Evangelista L, Chiesa C, Chiti A. Clinical Applications of Nuclear Medicine Targeted Therapy. Springer 2018. ISBN 978-3-319-63067-0.

[15] Eskian M, Khorasanizadeh M, Zinzani M P, Rezaei N. Radioimmunotherapy as the first line of treatment in non-Hodgkin lymphoma. Immunotherapy 2018; 10(8): 699-711

[16] Regan P M, Friedberg J W. Advancing radioimmunotherapy and its future role in non-Hodgkin lymphoma. Future Oncology 2015, 11(10):1543-53.

[17] Kitajima K, Okada M, Kashiwagi T, Yoshihara K, Tokugawa T , Sawada A, Yoshihara S, Fujimori Y, Yamakado K. Early evaluation of tumor response to 9oY-ibritumomab radioimmunotherapy in relapsed/ refractory B cell non-Hodgkin lymphoma: what is the optimal timing for FDG-PET/CT?. Europen Radiology 2019, 29(7):3935-3944.

[18] Repetto-Llamazares A H V, Malenge M M, O’Shea A, Eiríksdóttir B, Stokke T, Larsen R H, Dahle J. Combination of $177 \mathrm{Lu}$-lilotomab with rituximab significantly improves the therapeutic outcome in preclinical models of non-Hodgkin's lymphoma.

[19] Consolidative Radioimmunotherapy After Chemoimmunotherapy in Patients With Histologic Transformation of Indolent Non-Hodgkin Lymphoma. European Journal of Hematology 2018, 101:522531. 